\title{
STUDI TERHADAP TINDAK PIDANA KEHUTANAN DALAM PENEBANGAN HUTAN DILUAR RENCANA KERJA TAHUNAN PADA PEMILIK IZIN USAHA PEMANFAATAN HASIL HUTAN KAYU
}

\author{
Alasman Mpesau ${ }^{1 *}$ \\ ${ }^{1 *}$ Fakultas Hukum, Universitas Muhammadiyah Kendari, Indonesia, email: \\ asman.sultra@yahoo.com (corresponding)
}

\begin{abstract}
The problems in this study is deforestation outside the Annual Work Plan (RKT) on Timber Product Utilization Business License owner (IUPHHK) as acts against forestry administration law based on article 74 Government Role Number 6 of 2007. However, if it is viewed from its effect on the destruction of forest which is done without planning, logging area map, work target in Annual Work Plan (RKT) can destruct the forest. This research is a descriptive analysis which describe the problems in this research, then the analysis is carried out based on the principles of criminal law and forestry legislation. Deforestation acts outside the Annual Work Plan (RKT) on Timber Product Utilization Business License owner (IUPHHK) is forestry criminal law based on Article 50 Chapter (2) of Law Number 41 of 1999 of forestry. It becaused permission of the forest cultivation is in only refers to certain area. Therefore, if it is done outside the mentioned area, it is categorized as illegal logging and it can destruct the forest.
\end{abstract}

Keywords: Forestry, Annual Work Plan, Criminal Act.

\section{PENDAHULUAN}

Kerusakan lingkungan khususnya pada sektor kehutanan sekarang ini ternyata tidak hanya diakibatkan oleh tangan manusia yang melakukan penebangan liar (illegal logging), tetapi lebih pada ketidak tegasan peraturan perundang-undangan yang mengatur sanksi hukum terhadap pelaku pengrusakan hutan. Pemerintah dengan kebijakannya telah memberikan ruang pemanfaatan sumber daya hutan dengan fasilitas Izin Usaha Pemanfaatan Hasil Hutan Kayu (IUPHHK) kepada pihak BUMS, BUMN, BUMD, dan Koperasi. Hal ini berdasarkan Pasal 1 Ayat 13 PP No. 6 Tahun 2007 Tentang Tata Hutan Dan Penyusunan Rencana Pengelolaan Hutan, Serta Pemanfaatan Hutan menyebutkan Izin usaha pemanfaatan hasil hutan kayu yang selanjutnya disingkat IUPHHK adalah izin usaha yang diberikan untuk memanfaatkan hasil hutan berupa kayu dan/atau bukan kayu dalam hutan alam pada hutan produksi melalui kegiatan pemanenan atau penebangan, pengayaan, pemeliharaan dan pemasaran. 
Pada pemilik IUPHHK diwajibkan untuk menyusun semua program, perencanaan dan sasaran dalam jangka waktu 10 (sepuluh) atau disebut dengan RKU dan dijabarkan dalam perencanaan per satu tahun (RKT) yaitu semua informasi tentang sasaran, indikator dan target kinerja yang akan dicapai, termasuk penebangan hutan harus sesuai dengan RKT. Dari semua perencanan tersebut bertujuan untuk mencapai asas pengelolaan hutan lestari dan perlindungan hutan tetap terjaga serta kerusakan hutan dapat dihindari.

Pamanfaatan hasil hutan melalui penebangan hutan yang tidak sesuai dengan RKT masih terdapat perdebatan apakah merupakan perbuatan melawan hukum pidana kehutanan atau masuk dalam ranah pelanggaran hukum administratif. Basis argumen penebangan hutan di luar rencana kerja tahunan pada pemilik izin usaha pemanfaatan hasil hutan kayu dianggap sebagai pelanggaran administrasi karena berdasar pada asas legal bahwa IUPHHK merupakan alas legalitas izin pemanfaatan hutan, adapun RKT merupakan pedoman teknis agar pengaturan tata kelola pemanfaatan hutan dapat mencapai tujuan pengelolaan hutan lestari dan sarana supervisi dalam menjaga hak-hak negara atas sumber daya hutan melalui pajak dengan membayar PSDH dan DR. Oleh karena itu penerapan sanksi administrasi menganggap bahwa pemegang izin adalah subjek yang sah melakukan tindakan atas hak pemanfaatan hutan dalam wilayah izin yang diberikan dan RKT bentuk administrasi kehutanan semata dalam rangka tertib pengelolaan hutan guna tercipta pengelolaan hutan lestari.

Sementara argumen yang mendasarkan penebangan hutan di luar RKT, merupakan tindak pidana kehuatanan bahwa izin diberikan menunjuk arel kawasan hutan tertentu, RKT dibuat sebagai pedoman teknis pemegang IUPHHK dalam melaksanakan aktifitas dan kegiatannya, jika penebangan hutan tidak sesuai dengan perencanaan yang disusun dalam RKT maka sudah dapat dipastiakan akan berakibat pada kerusakan hutan. Kepada pemegang IUPHHK jika melakukan kegiatan termasuk penebangan hutan yang berakibat pada kerusakan hutan adalah tindak pidana kehutanan sesuai dengan Pasal 50 Ayat (2) Undang-Undang No. 41 Tahun 1999 tentang Kehutanan "Setiap orang yang diberikan izin usaha pemanfaatan kawasan, izin usaha pemanfaatan jasa lingkungan, izin usaha pemanfaatan hasil hutan kayu dan bukan kayu, serta izin pemungutan hasil hutan kayu dan bukan kayu, dilarang melakukan kegiatan yang menimbulkan kerusakan hutan".

Berdasarkan hal tersebut di atas menjadi penting bagi penulis untuk melakukan penelitian yaitu apakah penebangan hutan diluar rencana kerja tahunan pada izin usaha pemanfaatan hasil hutan kayu merupakan tindak pidana kehutanan.

\section{METODE PENELITIAN}

Bentuk penelitian ini adalah penelitan hukum normatif yaitu menekankan pada data sekunder yakni dengan mempelajari dan mengkaji asas-asas pidana, serta peraturan perundangundangan terkait dengan penelitian ini (Soekanto \& Mamudji, 2010). Metode ini digunakan untuk menjawab rumusan masalah tentang apakah penebangan hutan diluar rencana kerja tahunan pada izin usaha pemanfaatan hasil hutan kayu merupakan tindak pidana kehutanan. Data yang digunakan bersifat kualitatif, dan disajikan dalam bentuk deskriptip analisis.

\section{HASIL DAN PEMBAHASAN}

\section{Tindak Pidana Kehutanan Terhadap Penebangan Hutan Diluar Rencana Kerja Tahunan Pada Pemilik Izin Usaha Pemanfaatan Hasil Hutan Kayu}


Ketentuan pidana kehutanan diatur pada Pasal 50 Jo Pasal 78 UU No. 41 Tahun 1999 Tentang Kehutanan. Pasal 50 UU No.41/1999 mengatur tentang pelarangan perusakan prasarana dan sarana perlindungan hutan. Selain itu, larangan diberikan pula pada perbuatan menduduki kawasan hutan secara tidak sah, perambahan kawasan hutan, penebangan pohon dalam kawasan hutan dengan radius tertentu, membakar hutan, menebang dan memanen pada lokasi-lokasi-lokasi yang telah dilarang. Larangan lain diberikan pada perbuatan eksplorasi bahan tambang pada kawasan hutan yang tidak diberi izin Menteri, mengangkut, menguasai, atau memiliki hasil hutan yang tidak dilengkapi bersama-sama dengan surat keterangan sahnya hasil hutan, dan banyak larangan lainnya.

Apabila Pasal 50 berisi larangan, maka pasal 78 UU No.40/1999 berisi ancaman pidana terhadap pelaku pelanggaran. Ancaman pidana bervariasi, mulai ancaman maksimal 1 tahun penjara, hingga maksimal ancaman 15 tahun penjara. Pidana denda pun diterapkan, mulai dari maksimal Rp. 50.000.000 (lima puluh juta rupiah) hingga paling banyak maksimal Rp. 10.000.000.000 (sepuluh miliar rupiah).

Selain itu, apabila ketentuan pidana kehutanan Pasal 50 Jo Pasal 78 UU No. 41 Tahun 1999 tentang Kehutanan, dicermati kembali, secara eksplisit tidak ada yang menyebutkan bahwa penebangan hutan diluar RKT pada pemegang IUPHHK adalah kategori tindak pidana kehutanan. Namun diatur pada Pasal 74 PP No. 6 Tahun 2007 merupakan pelanggaran administrasi dengan kewajiban membayar denda sebanyak 10 (sepuluh) kali Provisi Sumber Daya hutan (PSDH).

Berdasarkan hal tersebut, menjadi penting penulis terlebih dahulu menguraikan penyelenggaraan pengelolaan hutan melalui IUPHHK sehingga prinsip pengelolaan hutan lestari dapat tercapai. Sumberdaya hutan sebagai modal pembangunan nasional memberikan manfaat secara ekonomi, sebagai perlindungan sistem penyangga kehidupan, untuk itu pemerintah melaksanakan fungsinya melindungi hak-hak negara atas sumberdaya hutan berupa mengurus sumberdaya hutan berdasarkan peraturan perundang-undangan. Hak penguasaan sumber daya hutan kepada negara diatur dalam Pasal 21 Undang-undang No. 41 Tahun 1999 tentang Kehutanan, kewenangan negara mengurus sumberdaya hutan adalah menyelenggarakan pengelolaan hutan yang meliputi kegiatan; (a) tata hutan dan penyusunan rencana pengelolaan hutan, (b) pemanfaatan hutan dan penggunaan kawasan hutan, (c) rehabilitasi dan reklamasi hutan, (d) perlindungan hutan dan konservasi alam.

Penyelenggaraan pengelolaan hutan tersebut meliputi pemanfaatan hutan dilaksanakan berdasarkan prinsip tata kelola hutan lestari dan meningkatkan fungsi utamanya yang dilakukan melalui kegiatan Izin Usaha Pemanfaatan Hasil Hutan Kayu (IUPHHK). Pemanfaatan hutan terdiri dari kegiatan untuk memanfaatkan kawasan hutan, memanfaatkan jasa lingkungan, memanfaatkan hasil hutan kayu dan bukan kayu serta memungut hasil hutan kayu dan bukan kayu secara optimal dan adil untuk kesejahteraan masyarakat.

Pemerintah dalam pengelolaan hutan diberikan hak pemanfaatan kepada pemegang IUPHHK. Dalam konteks hukum administarasi negara, IUPHHK merupakan pekerjaan besar menyangkut kepentingan umum yang tidak mampu dijalankan sendiri oleh pemerintah yang sebenarnya pekerjaan itu menjadi tugas dari pemerintah, tetapi oleh pemerintah diberikan hak penyelenggaraannya kepada pemegang izin atau perusahaan-perusahaan swasta.

Segala aktifitas dan kegiatan pemilik IUPHHK dijabarkan dalam bentuk Rencana Kerja Usaha Pengelolaan Hasil Hutan Kayu (RKU-PHHK) untuk perencanaan kegiatan selama 10 
(sepuluh) tahun dan Rencana Kerja Tahunan Pengelolaan Hasil Hutan Kayu (RKT-PHHK) selama 1 (satu) tahun yang disusun berdasarkan potensi aktual sumber daya hutan. RKU dan RKT merupakan dasar pelaksanaan kegiatan IUPHHK, artinya tanpa menyusun RKU dan RKT maka pemegang IUPHHK tidak bisa menjalankan usaha pemanfaatan hasil hutan.

Pokok dan uraian kegiatan yang dimuat dalam RKT-PHHK bagi pemegang IUPHHK yang merupakan subsistem dari sistem pengelolaan hutan dengan filosofi lestari antara lain:

\section{Penataan Areal Kerja (PAK)}

Pada penataan arel kerja bertujuan untuk membagi blok atau pemetaan tata kerja sehingga pada saat pelaksanaan kegiatan penebangan dapat berjalan sesuai dengan perencanaan pengelolaan hutan terpadu. Yang didalamnya untuk menata areal kerja sehingga kita dapat mengetahui batas arel hutan yang dizinkan untuk dilakukan penebangan hal ini dilaksanakan 3 tahun sebelum penebangan.

\section{Inventarisasi Tegakan Sebelum Penebangan (ITSP)}

Kegiatan meliputi pencatatan, pengukuran, penandaan pohon yang dilindungi dan dipelihara sampai dengan rotasi berikutnya dalam areal blok kerja tahunan untuk mengetahui:

a. Data pohon inti yang mencakup jumlah, jenis, dan diameternya.

b. Data pohon yang dilindungi yang mencakup jumlah, jenis, dan diameternya.

c. Data pohon yang akan dipanen yang mencakup jumlah, jenis, diameter, dan tinggi bebas cabang.

Inventarisasi tegakan sebelum penebangan bertujuan agar data penyebaran pohon yang akan ditebang antara lain meliputi komposisi jenis, jumlah, dan volume pohon.

\section{Pembukaan Wilayah Hutan (PWH)}

Kegiatan penyediaan prasarana wilayah bagi kegiatan produksi kayu, pembinaan hutan, perlindungan hutan, inspeksi kerja, transportasi sarana kerja, dan komunikasi antar pusat kegiatan. Pembukaan hutan diwujudkan oleh penyediaan jaringan angkutan, barak kerja, penimbunan kayu, dan lain-lain. Maksudnya untuk merencanakan pembuatan jalan angkutan dan prasarana lainnya yang berkaitan erat dengan kegiatan pengusahaan hutan. Tujuannya adalah untuk menyiapkan jalan angkutan dan prasarana lainnya (jembatan, gorong-gorong dan lain-lain) dalam upaya untuk kelancaran angkutan produksi hasil hutan dari masing-masing blok tebangan.

\section{Penebangan pohon}

Penebangan adalah kegiatan pengambilan kayu dari pohon-pohon dalam tegakan yang berdiameter sama dengan atau lebih besar dari diameter batas yang ditetapkan. Kegiatan penebangan pohon meliputi pekerjaan penentuan arah rebah, pelaksanaan penebangan, pembagian batang, pengupasan, dan pengangkutan kayu bulat dari tempat pengumpulan kayu ke tempat penimbunan kayu maksudnya melaksanakan pemanfaatan kayu secara optimal dari blok rencana yang telah disahkan atas pohon-pohon yang berdiameter lebih besar dari batas diameter yang telah ditetapkan, dan meminimalkan kerusakan terhadap tegakan tinggal. Tujuannya adalah untuk mendapatkan hasil dan keuntungan perusahaan berupa kayu dengan jumlah cukup dan mutu yang memenuhi persyaratan.

\section{Pengayaan/Rehabilitasi}

Kegiatan penanaman pada areal bekas tebangan, dengan tujuan untuk memperbaiki komposisi jenis, penyebaran pohon dan nilai tegakan. Maksud pengayaan/rehabilitasi adalah untuk menambah jumlah anakan semai dengan cara penanaman pada bagian-bagian areal bekas tebangan yang tidak atau kurang memiliki nilai komersil sebanyak yang dipersyaratkan dan penanaman pada 
areal terbuka sepertigabelas tempat pengumpulan kayu dan tempat penimbunan kayu yang tidak berfungsi lagi serta areal terbuka lainnya. Tujuannya untuk memperbaiki komposisi jenis dan penyebaran permudaan jenis komersial dan untuk mengupayakan peningkatan nilai dan produktivitas tegakan tinggal.

Salah satu kewajiban pemilik IUPHHK melakukan Penataan Areal Kerja (PAK) meliputi kegiatan penataan blok dan pembagian petak untuk memastikan batas-batas areal hutan yang akan ditebang atau areal hutan diizinkan untuk dimanfaatkan. Pembagian blok pada dasarnya sudah dituangkan dalam peta yang disusun dalam RKU, sedangkan dalam RKT berupa kegiatan tata batas blok di lapangan dan kemudian dibagi ke dalam petak sesuai peruntukannya. Penebangan dilakukan sebelum ada penataan batas areal kerja, sudah dapat dipastikan terjadi penebangan di luar RKT yang pada akhirnya akan mengakibatkan kerusakan hutan.

Kerusakan hutan, pada penjelasan Pasal 50 Ayat (2) Undang-Undang No. 41 Tahun 1999 tentang Kehutanan, adalah perubahan fisik, sifat fisik atau hayatinya yang menyebabkan hutan tersebut terganggu atau tidak dapat berperan sesuai dengan fungsinya. Setiap kegiatan pemanfaatan hutan dapat dipastikan menimbulkan perubahan fisik, sifat fisik, hilangnya hayati dan hutan tidak dapat berperan sesuai fungsinya. Apabila dalam kegiatan pemanfaatan pada izin usaha pemanfaatan hasil hutan kayu yang dijabarkan melalui RKT yang didalamnya ada kegiatan penebangan hutan, pembuatan jalan hutan, pengambilan hasil tebangan dalam hutan yang dapat menyebabkan rusaknya tumbuhan bawah dan dengan masuknya alat-alat berat dalam kawasan hutan akan merusak sifat fisik dan kimia tanah.

Oleh karena itu penulis akan melakukan studi tindak pidana kehutanan dengan permasalahan penebangan hutan diluar RKT pada pemilik IUPHHK yang berdasarkan peraturan perundang-undangan Pasal 74 PP No. 6 Tahun 2007 merupakan pelanggaran administrasi dengan denda sebanyak 10 (sepuluh) kali Provisi Sumber Daya hutan (PSDH). Akan diuraikan dalam 3 (tiga) pembahasan berikut; pertama melakukan perbuatan; Kedua, perbuatan melawan hukum; Ketiga, dampak kerugian yang diakibatkan perbuatan tersebut (Supardjadja, 2002) (Agustina, 2003).

\section{Melakukan perbuatan}

Moeljatno mendefinisikan perbuatan adalah suatu keadaan atau kejadian yang ditimbulkan oleh suatu kelakukan orang, titik berat dari kelakukan adalah adanya akibat (Moeljatno, 2008). Oleh karena itu dengan adanya "akibat" disebabkan kelakukan atau perbuatan dari sipembuat (sipelaku).

Bahwa penebangan di luar blok RKT pada pemilik IUPHHK adalah aktifitas pengambilan kayu dari pohon-pohon dalam tegakan di luar batas-batas areal hutan yang diizinkan yang sudah ditetapkan dalam Rencana Kerja Tahunan (RKT). Berdasarkan penjelasan tersebut di atas unsur "melakukan perbuatan" sebagai kreteria terpenuhinya unsur perbuatan melawan hukum yaitu "aktifitas pengambilan kayu dari pohon-pohon tegakan" sudah terpenuhi.

\section{Perbuatan melawan hukum}

"Perbuatan melawan hukum" pada ketentuan hukum pidana diartikan memiliki 4 (empat) pengertian yaitu perbuatan melawan hukum umum, perbuatan melawan hukum khusus, perbuatan melawan hukum formal dan perbuatan melawan hukum material (Hiariej, 2006). Oleh Ch.J. Enscede perbuatan melawan hukum umum diartikan sebagai syarat umum dapat dipidananya suatu perbuatan. Perbuatan pidana adalah suatu perbuatan manusia yang termasuk dalam rumusan pasal 
hukum pidana, bersifat melawan hukum, dan terdapat kesalahan yang dapat dikenakan pada pembuat (Supardjadja, 2002).

Perbuatan melawan hukum khusus, biasanya kata "melawan hukum" dicantumkan dalam rumusan pasal. Sehingga kata melawan hukum merupakan syarat yang harus dicantumkan dalam rumusan pasal agar perbuatan tersebut dapat dihukum sesuai dengan ketentuan pidana. Pandangan Jan Remmelink, bahwa barang siapa yang melanggar segala ketentuan yang diatur dalam peraturan perundang-undangan pidana artinya sesuangguhnya dia telah melakukan tindak pidana berarti perbuatan tersebut adalah perbuatan melawan hukum (Supardjadja, 2002). Sehingga dapat dimaknai walaupaun kata "melawan hukum" tidak dituliskan dalam rumusan pasal namun secara implisit kata "melawan hukum" dianggap ada dalam rumusan pasal tersebut (Supardjadja, 2002).

Perbuatan melawan hukum formal mengandung arti telah terpenuhinya rumusan delik baik itu sebaian dari unsur-unsurnya maupun semua. Sebaliknya perbuatan melawan hukum material ialah bertentangan hukum tidak tertulis atau hukum yang hidup dalam masyarakat, asas-asas kepatutan atau nilai-nilai keadilan dan kehidupan sosial dalam masyakat (Arief, 2005).

Pada penebangan hutan di laur RKT pada pemilik IUPHHK berdasarkan peraturan perundang-undangan Pasal 74 PP No. 6 Tahun 2007 sebagai pelanggaran administrasi dengan keharusan membayar denda sebanyak 10 (sepuluh) kali PSDH. Dari sanksi denda tersebut maka penulis bertolak dari ilmuwan hukum pidana van Bemmelen bahwa sesungguhnya tidak ada perbedaan antara perbuatan melawan hukum dalam hukum pidana dengan arti hukum melawan hukum di bidang hukum perdata (Supardjadja, 2002). Pendapat Van Bemmelen ini diperkuat oleh Pompe bahwa makna wederrechtelijk (perbuatan melawan hukum dalam hukum pidana) memilik arti yang sama dengan onrechtmatige (perbuatan melanggar hukum dalam hukum perdata) dengan merujuk pada putusan Hoge Raad, 31 januari 1919, meliputi (Agustina, 2003) (Hiariej, 2006):

1. Bertentangan dengan kewajiban hukum si pelaku.

2. Melanggar hak subjektif orang lain.

3. Melanggar kaidah tata susila.

4. Bertentangan dengan asas kepatutan, sikap hati-hati yang seharusnya dimiliki oleh seseorang dengan pergaulan sesama warga masyarakat atau terhadap harta benda orang lain.

Berdasarkan penjelasan tersebut di atas penebangan hutan di luar blok Rencana Kerja Tahunan (RKT) pada pemilik Izin Usaha Pemanfaatan Hasil Hutan Kayu (IUPHHK) unsurunsurnya dapat terpenuhi pada ketentuan pidana kehutanan Pasal 50 Ayat (2) Undang-Undang No. 41 Tahun 1999 tentang Kehutanan "Setiap orang yang diberikan izin usaha pemanfaatan kawasan, izin usaha pemanfaatan jasa lingkungan, izin usaha pemanfaatan hasil hutan kayu dan bukan kayu, serta izin pemungutan hasil hutan kayu dan bukan kayu, dilarang melakukan kegiatan yang menimbulkan kerusakan hutan", unsur-unsurnya sebagai berikut:

1. Setiap orang;

2. Yang diberikan izin usaha pemanfaatan hasil hutan kayu;

3. Melakukan kegiatan yang menimbulkan kerusakan hutan.

Unsur pertama: "setiap orang" dalam perkembangan sistem pertanggungjawaban pidana sejak diakuinya korporasi sebagai subjek hukum pidana. Secara teoritis ada dua teori sistem pertanggungjawaban pidana korporasi sebagai subjek hukum pidana yaitu teori identifikasi, dan teori vicarious liability.

1. Teori identifikasi; bahwa korporasi dapat melakukan sejumlah delik secara langsung melalui orang-orang yang sangat berhubungan erat dengan korporasi dan dipandang sebagai korporasi 
itu sendiri (Arief, 2002). Ketika individu melakukan suatu kesalahan, maka kesalahan itu pada dasarnya adalah kesalahan korporasi. Jadi individu identik dengan korporasi. Yang dimaksud dengan individu identik dengan korporasi adalah direktur, sehingga dikatakan bahwa tindakan direktur merupakan tindakan dari korporasi asal saja tindakan tersebut masih dalam ruang lingkup pekerjaannya dan demi keuntungan korporasi (Hanafi, 1999).

2. Teori Vicarius liability; suatu teori kesalahan yang dilakukan oleh seseorang namun yang mempertanggungjawabkan kesalahan tersebut adalah orang lain tetapi masih dalam wilayah ruang lingkup pekerjaan yang sama, atau biasa disebut pertanggungjawaban pengganti (Arief, 2002).

Berdasarkan penjelasan tersebut di atas, maka jelaslah unsur "setiap orang" adalah pemilik izin pemanfaatan hutan baik individu, badan hukum, maupun badan usaha.

Unsur kedua: “... yang diberikan izin usaha pemanfaatan hasil hutan kayu” berdasarkan Pasal 1 Angka (13) PP No. 6 Tahun 2007 tentang Tata Hutan Dan Penyusunan Rencana Pengelolaan Hutan, Serta Pemanfaatan Hutan, yang dimaksud dengan izin usaha pemanfaatan hasil hutan kayu adalah izin usaha yang diberikan untuk memanfaatkan hasil hutan berupa kayu dalam hutan alam pada hutan produksi melalui kegiatan pemanenan atau penebangan, pengayaan, pemeliharaan dan pemasaran. Subyek pemegang izin usaha pemanfaatan hasil hutan kayu adalah koperasi, BUMS, BUMN, dan BUMD yang izin pemanfaatan hutannya diterbitkan oleh pejabat berwenang melalui Surat Keputusan (SK) oleh Bupati/Walikota, Gubernur atas nama (a.n) Menteri Kehutanan.

Jadi unsur yang kedua: "Yang diberikan Izin Usaha Pemanfaatan Hasil Hutan Kayu (IUPHHK)" yaitu dapat dibuktikan melalui Surat Keputusan (SK) dari pejabat yang berwewenang, yang dimaksud dengan pejabat yang berwenang adalah pejabat pusat atau daerah yang diberi wewenang oleh undang-undang untuk memberikan izin.

Unsur yang ketiga: "Kegiatan yang menimbulkan kerusakan hutan" menurut penjelasan Pasal 50 Ayat (2) Undang-Undang No. 41 Tahun 1999 tentang Kehutanan yang dimaksud dengan kerusakan hutan adalah terjadinya perubahan fisik, sifat fisik, atau hayatinya, yang menyebabkan hutan tersebut terganggu atau tidak dapat berperan sesuai dengan fungsinya.

Fungsi hutan sendiri sebagaimana Pasal 6 Undang-Undang No. 41 Tahun 1999 tentang Kehutanan bahwa hutan mempunyai tiga fungsi, yaitu:

1. Fungsi konservasi adalah kawasan hutan dengan ciri khas tertentu, yang mempunyai fungsi pokok pengawetan keanekaragaman tumbuhan dan satwa serta ekosistemnya;

2. Fungsi lindung adalah kawasan hutan yang mempunyai fungsi pokok sebagai perlindungan sistem penyangga kehidupan untuk mengatur tata air, mencegah banjir, mengendalikan erosi, mencegah intrusi air laut, dan memelihara kesuburan tanah;

3. Fungsi produksi adalah kawasan hutan yang mempunyai fungsi pokok memproduksi hasil hutan.

Lebih lanjut berdasarkan Pasal 6 Ayat (2) huruf c di atas, hutan mempunyai fungsi produksi yaitu kawasan hutan yang mempunyai fungsi pokok memproduksi hasil hutan. Maka sesungguhnya maksud dan tujuan pemberian IUPHHK adalah untuk menjalankan fungsi hutan produksi yakni menghasilkan kayu yang bersumber dari lokasi hutan produksi. Sedangkan perlunya RKT adalah agar dalam kegiatan pemanfaatan hutan oleh pemegang IUPHHK tidak menimbulkan kerusakan hutan guna mencapai pengelolaan hutan lestari, yakni pengelolaan hutan 
yang ditinjau dari 3 (tiga) aspek yakni aspek produksi, ekologi dan sosial. Berdasarkan hasil Konferensi Perlindungan Hutan Tingkat Menteri di Eropa, Helsinki tahun 1993, pengelolaan hutan lestari adalah pengurusan dan penggunaan hutan dan lahan hutan melalui cara dan pada tingkat yang dapat mempertahankan keanekaragaman hayati, beserta produktivitas, kapasitas regenerasi, serta kemampuan mempertahankan hidup dan potensinya, untuk memenuhi fungsi-fungsi ekologi yang sesuai, ekonomi dan sosial pada saat ini dan di masa mendatang, serta tidak menyebabkan kerusakan bagi ekosistem lainnya.

Penebangan hutan di luar RKT dapat menyebabkan terbukanya ruang tegakan pohon seningga panas matahari langsung dapat masuk kepermukaan lantai tanah berakibat pada perubahan kelembapan tanah atau unsur hara tanah yang menjadi kering. Dengan kondisi demikian menyebabkan "perubahan sifat fisik dan kimia tanah" yang menimbulkan hilangnya flora dan vegetasi sehingga hutan tersebut terganggu atau tidak dapat berperan sesuai dengan fungsinya yaitu fungsi konservasi, lindung dan produksi. Flora adalah kumpulan suatu jenis tumbuhtumbuhan yang terdapat pada suatu daerah tertentu, sedangkan Vegatasi adalah masyarakat tumbuh-tumbuhan yang terdiri dari individu-individu jenis atau kumpulan populasi jenis (Arif, 1994). Oleh karena itu dapat disimpulkan bahwa penebangan hutan di luar RKT pada IUPHHK terbukti mengakibatkan kerusakan hutan yang dalam peraturan perundang-undangan adalah perbuatan melawan hukum administrasi. Maka unsur perbuatan melawan hukum formal dengan sendirinya telah terpenuhi pada Pasal 50 Ayat (2) Undang-Undang No. 41 tahun 1999 tentang Kehutanan.

Perbuatan melawan hukum material yaitu bertentangan dengan hukum adat yang hidup ditengah masyarakat sejak turun-temurun yang didalamnya menganut asas-asas kepatutan berupa nilai kepantasan dan tidak pantas dalam kehidupan social masyarakat. Masyarakat Indonesia yang memiliki nilai-nilai dan kultur tradisional sejak zaman dahulu, meyakini bahwa hutan memiliki nilai spritual, yakni percaya bahwa hutan atau komponen biotik dan abiotik yang ada di dalamnya sebagai obyek yang memiliki kekuatan nilai supranatural antara alam, manusia, dengan Tuhan yang mereka patuhi (Simon, 2008) (Rianse \& Abdi, 2010). Oleh karena itu kerusakan hutan akibat dari penebangan hutan yang dilakukan oleh pemegang izin yang tidak berdasarkan rencana kerja tahunan dapat merubah perspektif dan perilaku masyarakat adat setempat terhadap hutan, dengan demikian sifat melawan hukum material dengan sendirinya terpenuhi.

Pemaparan diatas yaitu perbuatan melawan hukum formal dan materil, serta perbuatan melawan materil telah terpenuhi maka dengan sendirinya sifat melawan hukum umum sebagai syarat dapat dipidananya suatu perbuatan dengan sendirinya terpenuhi. Sedangkan perbuatan melawan hukum khusus dimaknai kata "melawan hukum" harus dicantumkan dalam rumusan delik. Dengan merujuk pendapat pakar hukum Jan Remmelink bahwa siapa pun yang terbukti melanggar ketentuan pidana maka dengan sendirinya dapat dimakanai bahwa dia telah melakukan perbutan melawan hukum. Walaupun kata "melawan hukum" tidak dicantumkan dalam ketentuan Pasal 50 Ayat (2) Undang-Undang No. 41 Tahun 1999 tentang Kehutanan namun secara implisit kata "melawan hukum" dianggap ada.

Terpenuhinya 4 (empat) unsur sifat melawan hukum pidana yaitu melawan hukum formal, sifat melawan hukum material, sifat melawan hukum umum dan sifat melawan hukum khusus maka terhadap perbuatan melawan hukum administrasi kehutanan dalam tindak pidana kehutanan ketantuan Pasal 50 Ayat (2) Undang-Undang No. 41 Tahun 1999 tentang Kehutanan semuanya telah tepenuhi unsur-unsurnya. 


\section{Dampak Kerugian Negara Terhadap Penebangan Hutan Diluar RKT Pada Pemilik IUPHHK}

Adapun kerugian negara terhadap penebangan hutan diluar RKT pada pemilik IUPHHK yaitu berakibat pada kerusakan hutan hingga berdampak pada kerugian ekonomi, sosial, budaya, dan lingkungan. Hal ini merupakan kosekwensi logis dari fungsi hutan yang pada hakekatnya adalah sebuah ekosistem yang di dalamnya mengandung tiga fungsi dasar, yaitu fungsi produksi (ekonomi), fungsi lingkungan (ekologi), serta fungsi sosial (Iskandar \& Siran, 2000).

Fungsi sosial budaya hutan dapat dilihat dengan adanya keterkaitan baik moril maupun spritual antara hutan dengan masyarakat yang tinggal di dalam dan di sekitar hutan, baik dalam hubungannya sebagai sumber mata pencaharian, hubungan religius, hubungan adat ikut terpengaruh akibat dari penebangan hutan oleh pemegang izin yang tidak sesuai dengan rencana kerja tahunan pada akhirnya merubah perspektif dan prilaku masyarakat hukum adat setempat terhadap hutan.

Kerusakan hutan akibat dari penebangan hutan diluar rencana kerja tahunan ditinjau dari fungsi lingkungan (ekologi) adalah hilangnya sejumlah pohon-pohon tertentu, ekosistem alam menjadi rusak yang tidak terkendali dimana sinar matahari langsung kepermukaan tanah berdampat pada penurunan tingkat kesuburan tanah. Dengan adanya menurunnya kesuburan tanah tersebut meyebabkan berubahnya unsur hara tanah yang berakibat hilangnya flora dan vegetasi.

Dampak global dari pengurangan vegetasi adalah berkaitan dengan peran vegetasi dalam memanfaatkan karbondioksida $\left(\mathrm{CO}^{2}\right)$ dari atmosfer. Jika vegetasi berkurang, sedangkan emisi $\mathrm{CO}^{2}$ terus meningkat, maka jelas akan mengakibatkan peningkatan $\mathrm{CO}^{2}$ dalam atmosfer yang tidak terkendali (Arif, 1994). Dari aspek ekonomi, dapat merugikan keuangan negara dari pendapatan pajak dengan tidak membayar Provisi Sumber Daya Hutan (PSDH) dan Dana Reboisasi (DR). Berdasarkan hasil penelitian David W. Brown pengamat ekonomi kehutanan dari Department For International Development (DFID), mengkalkulasikan kerugian finansial yang ditanggung pemerintah akibat penebangan hutan di luar rencana kerja tahunan pada pemilik IUPHHK sebesar US\$ 1,632 miliyar (Setiono \& Husein, 2005).

Dengan penjelasan tersebut di atas, bahwa pemanfaatan hutan melalui IUPHHK, dalam pemberian izinnya telah dikaji aspek kelestarian hutan berdasarkan prinsip pengelolaan hutan lestari. Untuk mencapai pengelolaan hutan lestari tersebut dijabarkan dalam bentuk Rencana Kerja Tahunan (RKT), dengan demikian Rencana Kerja Tahunan (RKT) merupakan substansi teknis kehutanan untuk mengantisipasi dan memastikan kepada pemegang izin dalam segala aktifitas dan kegiatannya tidak menimbulkan kerusakan hutan karena akibat dari kerusakan hutan tidak hanya dirasakan oleh masyarakat pinggir hutan, namun dirasakan secara nasional, regional maupun internasional.

\section{KESIMPULAN}

Penebangan hutan diluar RKT pada pemilik IUPHHK adalah tindak pidana kehutanan berdasarkan ketentuan Pasal 50 Ayat (2) undang-undang No. 41 Tahun 1999 tentang Kehutanan. Sebab izin pemanfaatan hutan yang diberikan yaitu menunjuk terhadap areal hutan tertentu. Maka kalau aktivitas penebangan dilakukan di luar areal yang ditunjuk berdasarkan izin yang diberikan 
artinya dia tidak memiliki izin untuk melakukan kegiatan penebangan di luar areal yang diizinkan maka kegiatannya adalah kegiatan illegal yang berakibat pada kerusakan hutan.

\section{DAFTAR PUSTAKA}

Agustina, R. (2003). Perbuatan Melawan Hukum. Program Pascasarjana Fakultas Hukum Universitas Indonesia.

Arief, B. N. (2002). Sari Kuliah Perbandingan Hukum Pidana. Raja Grafindo Persada.

Arief, B. N. (2005). Masalah Kodifikasi, Unifikasi dan Konsep Ajaran Sifat Melawan Hukum Material dalam RUU KUHP.

Arif, A. (1994). Hutan Hakekat dan Pengaruhnya terhadap Lingkungan. Yayasan Obor Indonesia.

Hanafi. (1999). Reformasi dari Sistem Pertanggungjawaban Pidana. Jurnal Hukum, 6(11), 44.

Hiariej, E. O. S. (2006). Telaah Kritis Putusan Mahkamah Konstitusi dan Dampaknya Terhadap Pemberantasan Korupsi. Mimbar Hukum, XVIII(3).

Iskandar, U., \& Siran, S. A. (2000). Pola Pengelolaan Hutan Tropika, Alternatif Pengelolaan Hutan yang Selaras dengan Desentralisasi dan Otonomi Daerah. Bayu Indra Grafika.

Moeljatno. (2008). Azas-Azas Hukum Pidana (8th ed.). Rineka Cipta.

Rianse, U., \& Abdi. (2010). Agroforestri: Solusi Sosial dan Ekonomi Pengelolaan Sumber Daya Hutan. Alfabeta.

Setiono, B., \& Husein, Y. (2005). Kejahatan Kehutanan dan Mendorong Prinsip Kehati-hatian Perbankan untuk Mewujudkan Pengelolaan Hutan yang Berkelanjutan. Center for International Forestry Research (CIFOR).

Simon, H. (2008). Pengelolaan Hutan Bersama Rakyat (Cooperative Forest Managemand) Teori dan Aplikasi Pada Hutan Jati di Jawa. Pustaka Pelajar.

Soekanto, S., \& Mamudji, S. (2010). Penelitian Hukum Normatif Suatu Tinjauan Singkat. Raja Grafindo Persada.

Supardjadja, K. E. (2002). Ajaran Sifat Melawan Hukum Material dalam Hukum Pidana Indonesia: Studi tentang Penerapan dan Perkembangannya dalam Yurisprudensi. Alumni. 